\title{
Stakeholder Relationships in the Framework of R\&D-based Startups: Evidence from Turkey
}

\author{
Elif Kalayci \\ Assistant Professor, Department of Economics, elif.kalayci@atilim.edu.tr \\ Atilim University, Kızılcaşar Mahallesi, İncek / Ankara, Turkey.
}

\begin{abstract}
$\mathrm{I}$

$\mathrm{t}$ is widely acknowledged that R\&D- based start-ups play a significant role in the economic growth of many countries. However, founding such an enterprise is a risky endeavor, one that requires a balance between the technological search process and business capabilities. Most of the time these varied skills are found among several different people. The task becomes more difficult for recent engineering school graduates who are neither scientists nor business people. Therefore, it is critical for these new techno-entrepreneurs to conscientiously work on building relationships with stakeholders through whom they might access scientific knowledge on one hand and commercial knowledge on the other.

The paper explores the process of building relationships with stakeholders based on evidence from Turkish companies. It begins with a review of the literature, presenting the different theories concerning relationships with stakeholders as far as entrepreneurship is concerned. Then, it presents the methodology, coding and analysis of in-depth interviews with the founders of R\&D-based start-ups. The case profiles are considered with a focus on the following issues: the counterbalancing of stakeholder power, learning by the entrepreneur as a by-product of interactions with stakeholders, and the earning of

a reputation through ethical and passionate business practices. Building upon these preliminary findings, the author draws three main propositions that could be the subject of further research.

The main finding of this paper is that there are two opposing forces affecting the development of an R\&D -based start-up- challenger and supporter stakeholders. However, a stakeholder who was once a supporter could turn into a challenger or vice versa. The entrepreneur could benefit from the counterbalancing effect of these forces. Two major stakeholder groups emerged at the initial stage of the business: the family members and the state's grant-monitoring officers. Then, the ethical and passionate conduct of business by these start-ups could become a factor drawing third parties in, to become stakeholders of these start-ups. The nature and impact of these relationships should be researched further. Such an analysis allows one to understand how R\&D-based startups are established and what kind of problems they face when turning (hopefully) into large corporations. On such a basis, this could help governments develop more suitable support programs that would benefit and expand the opportunities available to the founders of new R\&Dbased firms.
\end{abstract}

Keywords: technological entrepreneurship; stakeholder relationships; challenger stakeholder; supporter stakeholder; causation logic; effectuation logic; R\&D-based startups; Turkey.
Citation: Kalayci E. (2017) Stakeholder Relationships in the Framework of R\&D-based Startups: Evidence from Turkey. Foresight and STI Governance, vol. 11, no 3, pp. 61-70. DOI: 10.17323/2500-2597.2017.3.61.70 
I n many countries, governments consider R\&D-based start-ups significant contributors to economic growth [Scottish Executive, 2001; OECD, 2003]. Given this role, one must analyze the experiences of these entities in order to understand how they are established and the problems they face as they turn (hopefully) into large corporations. Such an analysis could help governments develop more suitable support programs and open opportunities for new R\&D-based firms. Furthermore, these firms intend to launch R\&D-based products on the market and therefore face uncertainty in two distinct areas: one is research and development [Julien, 1995] and the other is commercialization [Gans, Stern, 2003].

In such a precarious environment, these start-ups need all the support they can get. Stakeholders are critical at this point because they are the providers of such resources. Thus, the founders of an R\&D-based start-up need to make deliberate efforts at turning third parties into stakeholders [Sarasvathy, Venkatamaran, 2011]. Sarasvathy and Venkatamaran assert: 'Almost the entirety of social network research takes networks mostly as a given and outside the control of human action' [Sarasvathy, Venkatamaran, 2011, p. 126]. Yet as negotiation research has demonstrated, it is not easy for people to reach mutually beneficial agreements [Bazerman, Neale, 1992]. Building a cohesive and committed relationship relies on an endogenous process of continuous interactions between the parties [Lawler, Yoon, 1996; Thompson et al., 2000].

Turkey as a developing country serves as an interesting case to illustrate the experiences of R\&D-based startups. Since 2010, the Turkish government has provided an increasing amount of seed funding to university graduates who intend to establish a start-up with the goal of developing a high-tech, R\&D-based product and commercializing it [MSIT, 2014]. The name of this program is 'Techno-Entrepreneurship'. However, to the best of our knowledge, as of 2016, no qualitative research on the experiences of these techno-entrepreneurs has been published.

The topic of the present research concerns how entrepreneurs build relationships with third parties as the potential stakeholders of an R\&D-based start-up. In section one; we begin with a literature review, presenting the different theories on stakeholder relationships as far as entrepreneurship is concerned. Section two presents our methodology, coding, and analysis based on the justified use of a qualitative approach. Section three contains our case profiles, while section four provides an analysis of the following themes: the counterbalancing of stakeholder power, learning by the entrepreneur as a by-product of stakeholder interactions, and earning one's reputation through ethical and passionate business practices. Building upon these preliminary findings, section five, draws three main hypotheses that could be the subject of further research, and section six presents the article's conclusions.

\section{Literature Review}

The establishment of an R\&D-based start-up is a risky endeavor that requires a balance between the technological search process and business capabilities. Not only must an entrepreneur focus on R\&D activities to create a feasible product, but he/she must also create a commercially viable and sustainable organization. Most of the time, R\&D capabilities and business capabilities are found among a variety of different individuals [Daniels, Hofer, 1993]. The task becomes more difficult for recent engineering graduates who are neither scientists nor business people. Therefore, it is critical for these new techno-entrepreneurs (those who set up a business based on R\&D) to develop strong relationships with stakeholders through which they can access both scientific knowledge and commercial know-how.

The resource dependence theory states that an organization is dependent upon accessible resources in its environment for its survival [Pfeffer, Salancık, 1978]. The extent of this dependence is directly proportional to the significance of a particular resource for the organization. Investors, those who control the resources, determine the subject of investment [Frooman, 1999; Pfeffer, Salancik, 1978]. In the case of R\&D-based start-ups, scientific and commercial knowledge are the critical resources they need. Thus, the owners of such resources are the people that the entrepreneur must reach and involve in the initial stages of founding an enterprise.

Stemming partly from the resource dependence theory, the stakeholder theory defines stakeholders as "any group or individual who can affect or is affected by the achievement of an organization's objectives" [Freeman, 1984, p. 46]. The stakeholder theory states that the salience of stakeholders depends on three main concepts power, legitimacy, and urgency. The power of a stakeholder emerges from the dependence of a firm on stakeholders for resources [Mitchell et al., 1997]. As the dependence of the organization on the resource increases, the power of the stakeholder on the organization also grows [Frooman, 1999]. The legitimacy of a stakeholder has to do with the negotiating relationship between the stakeholder and the start-up's managers. Those who have a claim on the start-up have legitimacy. Most of the time, power is assumed to be coupled with legitimacy, yet, not every legitimate stakeholder has power or influence such as the case of 'minority shareholders. The opposite also holds, illegitimate stakeholders could have great power as in the case of 'corporate raiders'. Urgency is defined as "the degree to which stakeholder claims call for immediate attention" [Mitchell et al., 1997, p. 867]. When legitimacy and urgency coincide, the need for being heard by decision-makers increases. When power and urgency are simultaneously present, the stakeholder takes action. When power, legitimacy and urgency all coincide, both parties acknowledge the situation and take action in a reciprocal manner.

As these theories were mainly conceptualized for existing firms, not start-ups, they fall short of identifying who should be the stakeholders of start-ups. The theory of effectuation proposed by Sarasvathy [Sarasvathy, 2001] was developed to explain entrepreneurship, but lacks an explanation regarding the relationships with stakeholders. There is a void in the literature on how stakeholder relationships are formed at the time of establishing a start-up, particularly when the start-up actively pursues R\&D.

Steyaert [Steyaert, 1997] claims that in order to comprehend entrepreneurship as a process, one has to study 'stories' of start-ups because they are context-dependent. The local conditions exert forces that shape the behavior of entrepreneurs. Thus, in this work, we chose to take a qualitative approach and collect local stories of R\&D-based start-ups in Ankara, Turkey. 
When a firm is in the process of being created, stakeholder relationships are already forming. As a result, entrepreneurs choose the stakeholders with whom they want to build such connections. The relationships they would invest in would be those with investors who would help them realize their start-up [Sarasvathy, 2001]. For instance, a recent engineering graduate, who wants to turn his class project into a commercial product most likely knows what knowledge he lacks but does not know where to find sources of knowledge and support. Furthermore, if he approaches a professor, will the professor spare his precious time on this project? Assuming he somehow comes up with a technologically feasible prototype, who should he ask for help when it is time to market the product, set up an enterprise, and finance the venture?

\section{Methodology}

Evers et al. [Evers et al., 2012, p. 55] note: "the CEO/founder entrepreneur is the key decision maker for driving the companies forward from inception and leveraging their stakeholder relationships". Moving from this finding, in this study we conducted in-depth interviews with the founders of R\&D-based start-ups. In order to reach R\&D-based start-ups, we used a list of start-ups that participated in a project fair organized by the Ankara Development Agency in 2012. A common feature of these start-ups is that they were all founded in 2011 upon receiving seed capital of $100.000 \mathrm{TL}^{1}$ from the Turkish Ministry of Science, Industry and Technology on the condition that they engage in $\mathrm{R} \& \mathrm{D}$. We considered only those start-ups in the manufacturing sector so that we could have some common ground in the sample. Thus, we used criterion sampling [Patton, 2002]. The criterion was that the manufacturing sector start-ups that attended the project fair of the Ankara Development Agency in 2012. The attendees of the project fair were announced on a list containing the names and contact details of the entrepreneurs, the industry and some information about the product they intended to promote at the fair. One downside of using such a list is that not all entrepreneurs who received the techno-entrepreneurship grant from the Ministry of Science, Industry and Technology attended this fair. Therefore, there might be a bias towards those who were able to successfully develop a prototype in the year following the receipt of this grant. However, since there was no other way to obtain the contact information of these techno-entrepreneurs, we had to deal with what information was publicly available. Between the months of June and August 2015, we contacted 12 different entrepreneurs in the manufacturing sector to conduct in-depth interviews. Since our aim was to explore the period of developing stakeholder relationships, and to avoid generalizing the findings, a small number of cases could be used to derive rich and meaningful information [Coviello, Jones, 2004]. According to Patton [Patton, 2002, p. 245]: "The validity, meaningfulness, insights generated from a qualitative inquiry have to do more with the information richness or the cases selected and the observational (analytical) capabilities of the researcher than with the sample size". Thus, we picked three cases for this study as they were the most rich and illustrative.

\section{Coding and Analysis}

Our work is built upon the principles of grounded theory, which was developed using inductive methods based on information gathered over the course of social research [Strauss, Curbin, 1990]. According to this theory, the research questions of the study are considered preliminary and are expected to change as findings are uncovered. Given that before conducting the research, the researcher observes only the outcome of what has taken place, he or she does not know how the processes unfolded. Therefore, the research questions take shape as the researcher learns the whole story from the perspective of the study subjects [Maxwell, 1996]. A guiding principle of grounded theory is constant comparison, which means the components of the theory are developed and refined throughout the study. As concepts emerge, they are compared with new data and refined until saturation takes place. In this study, the data was collected using semi-structured and open-ended interviews with founding entrepreneurs [Eriksson, Kovalainen, 2008]. The interviews were conducted at the interviewee's premises and yielded visual data on the work environment of the entrepreneurs. Voice recordings were transcribed as soon as possible after the interviews and reviewed for any errors by the researcher. Coding was performed using QDAMiner Lite software.

\section{Trustworthiness}

After each case was written, they were sent to the entrepreneurs or founding partners, who reviewed them for accuracy. In one case, the entrepreneur provided some supplemental information. All three approved our unbiased approach. To provide investigator triangulation, two evaluators reviewed the material in each case. This approach allowed us to compare and contrast independent judgements and interpretations concerning the content of the material.

\section{Case Profiles}

Firm A was founded by a chemistry major from a private university in Ankara in 2012. This was the founder's second start-up. In 2011, the founder received the techno-entrepreneurship grant and set up a lab in his family's summer house in the Kazan district outside of Ankara. After working for three months with a single employee, a university classmate, they were able to develop the prototype. Yet, they could not complete all the tests required for the project. One of the tests was not applicable to the materials they were using. For another test, there was not enough time to apply to the Turkish Standards Institute (TSI), so instead of TSI testing, the entrepreneur developed his own test for the prototype with the help of a friend. However, the academic monitor appointed by the ministry required word-for-word compliance with the project guidelines and finding that a test was missing, reported this violation to the ministry. As such, the activities of the firm were suspended. In 2012, after meeting his employee's boyfriend at a barbeque party and learning that his area of PhD research was laser technology, he asked if it was possible to develop a new laser hair removal device. Upon receiving 
an enthusiastic 'yes', the founder and his new partner began working on this project, applied for the technoentrepreneurship grant and received it one more time. The founder had high hopes for this product because the founder's aunt was running a beauty parlor and the founder knew laser hair removal devices on the market often burned the skin along with the hair, so a device that would not harm the user's complexion had a high chance of success on the market. While developing the laser hair removal device, the founder and his partner published two articles in a medical journal and received one patent. However, they ran out of cash and applied for a subsidy from the Scientific and Research Council of Turkey (TUBITAK) in 2013. Although their subsidy was approved in March, the money was delayed for eight months and did not arrive until September. Meanwhile the founder asked for help from his parents and they mortgaged their flat, which financed the firm in the interim period. Two days before the flat was to be sold, the cash they expected from TUBITAK arrived, which saved the apartment.

As of July 2015, the firm had nine employees, held a patent with two more applications pending. The firm had received support from an angel investor in return for $30 \%$ of the firm's shares. With the new investment, the firm's current goal is to launch the product on the domestic and two foreign markets.

Firm B has two partners, E.Ç and H.K. Both majored in mechanical engineering and met in 2003 when they were working on the design and development of a solar-powered car. By September 2010, they had applied for the techno-entrepreneurship grant for two different business ideas and had also accumulated work experience throughout this period. Having won R\&D grants for both business ideas, they first started out with two firms aimed at the same markets, municipalities that in the end were not prepared to buy their products. They therefore halted both projects and set up a design-based manufacturing firm as they saw a market in this area. Previously one of the partners, H.K., had worked with an Austrian firm and was still in contact with it. Upon a request from that firm, they created their first custom-made chandelier, which was installed on a U.S.-based intercontinental cruise line. The cruise-line, which was a client of the Austrian firm, was delighted with the product. This encouraged more orders and given that they only had a 44-square-meter office at a technopark, the founders soon felt they needed a larger space to begin manufacturing work in addition to design. In addition to the office, they decided to rent a four story-building with 800 square meters of closed space and 100 square meters of open area in the Organized Industrial Region in Ankara (OSTIM) ${ }^{2}$. On the ground floor manufacturing took place, the first floor hosted the office space, mechatronics works, and a dormitory. The basement and the second floor were allocated for storage, assembly lines and testing areas. E.C. explained the need for a dormitory: 'We get exhausted from work... Lose track of time... Need to look at the calendar to know which day it is, but I certainly know that in seven days this chandelier needs to be manufactured, assembled, installed, shipped, etc. ... For the past year, I have literally lived in this place.'

All of their sales were exported and they have not sold a single product on the domestic market. Their products are unique because they are custom-designed and manufactured per the wishes of the customer. They have local and international suppliers including those from: Egypt, Slovakia, the U.S., China, and Austria. In order to decide whether to work with an international supplier or not, they fly to the country, visit the firm, see the products and then make their decision. Thus, when H.K. leaves home to check out suppliers, he 'could leave for one or two weeks with a single piece of luggage, but may end up spending one to two months with the same luggage.' As of July 2015, the firm had 15 employees. The financial value of the project they have on hand, is the highest it has ever been in the company's entire history.

Firm $\mathrm{C}$ was founded by an Electricity and Electronics Engineering major from a private university in Ankara. In 2010, while she was a graduate student working on her thesis project under the guidance of a professor, she developed a unique product. At the time, this product was not being produced in Turkey. She developed the design and wrote an academic paper on it. This paper was submitted to an academic conference in Turkey, where it received the award for best student paper. After applying for the techno-entrepreneurship grant and receiving what she called 'free money', the firm was founded in April 2011 despite strong objections from her father. Her father, a civil servant turned entrepreneur disapproved of her efforts at creating a start-up, declaring 'you should be a civil servant, entrepreneurship is unbearably difficult, and you will have to sacrifice too much. If you take this grant, I will not talk to you'. Her mother also sided with her father. However, her older brother supported her, so she started her own venture and her father stopped talking to her. Initially she had no partners but her professor, who was the advisor for her thesis project and supported her whole-heartedly. The rector of the university also was a professor of hers, and upon hearing of her success in receiving seed funding (among all the grant receivers, she was the only grant recipient from her university), the rector offered her a free office with all utilities paid. By the time she began working, she had three former classmates looking for employment, so she offered them jobs. Together, they developed different versions of the first product. When it was time to find customers, they literally started knocking on doors around campus to tell potential customers that 'they were students who had created a product, would they be interested in buying it?' As they found customers and began manufacturing, they also began earning good profits. After deducting expenses and taxes, the entrepreneur distributed all earnings equally among her employees, as if they were her partners. However, one of her employees left for military service while another decided to become a civil servant and quit the company. In the meantime, the entrepreneur finished her master's degree studies and began a PhD program, both of which were focused on electronics. Her professor stood with her at all times. However, the university's support was not as reliable. There were a couple of times that the university administration asked her to leave and she started looking for a new place. The university administration either retreated or asked her to change her office to another building, which cost her as each time she moved, she had to change her legal address. As a result of these changes, she bought an office building to be safe in case the university administration decided they could no longer host her business. Yet, in her office at the university, with her remaining employee, she worked very hard (i.e., there were times when they worked for 20 hours a day). Together they acquired increasing amounts

${ }^{2}$ OSTİM is an organized industrial region in Ankara. Established in 1967, OSTİM accomodates 5,200 SMEs employing 60,000 people within an area of 5 million square meters ( http://www.ostim.org.tr/p/5244). 
of business and accumulated sound references. However, after a year or so, to her surprise, the entrepreneur found out that this employee had been doing business behind her back. This incident caused the entrepreneur so much stress that she developed diabetes. After parting ways with that employee and her dealing with health issues, she faced pressure from her father once again, who said: 'I will not die in peace before I see you working as a civil servant. Thus, she decided to switch career paths and found a teaching job at a state university, but could not stand the idea of closing down her firm. As a means of truce with her family, she took on the teaching job as a civil servant and made her mother a partner since she could not both own a firm and work as a civil servant at the same time. By that time, she had developed sound enough relationships with a manufacturing firm that took over her firm's manufacturing operations, which decreased her dependence on employees. In return, she began undertaking R\&D projects for that firm. She started to work part-time at the firm along with her teaching job. As of 2015, with one pending and one new patent application under review, the firm was a partnership with the entrepreneur in charge of R\&D. Manufacturing operations were outsourced to a 50-year-old local firm. As of July 2015, the firm had developed 150 different products and accumulated sound references through which new customers were coming to the firm.

\section{Analysis \\ Entrepreneurs benefit from the counterbalancing power of the stakeholders}

The 'story' of each start-up is unique but a common point emerging in all is the development of a start-up amidst, crudely speaking, two opposing forces. Tables 1-3 present a chronological summary of the milestones as these opposing forces take action. The aim here is to see when each stakeholder emerges in the timeline and the events defining a stakeholder's relationship with the entrepreneur. The left-hand column contains problematic or "challenger" stakeholders and the right-hand column contains "supporter" stakeholders. The numbers follow the chronological order of events that unfolded with each stakeholder. For each case, three periods are detected as indicated by period numbers in the column on the far left. A significant event marks the end of a period and the beginning of a new one.

On one hand, there are the challenger stakeholders and on the other, there are those who provide support. In each case, the challenger stakeholder is a different one, but to alleviate the pressure from the challenger stakeholders, the entrepreneur relies upon support from other stakeholders. For example, the entrepreneur in Case $\mathrm{C}$ had to face her father's strong opposition after receiving the seed funding. In this first instance of pressure from her father, she relies on three other stakeholders: her professor, her older brother and her alma mater's rector. Her professor supported her by saying: "My father did not allow me to start my own business. Had I given it a try, I may have been in a very different place. I am a professor now, fine, but you go ahead and try. If you fail, you fail, but at least you will know you have tried." Her older brother supported her and said: "Don't listen to them (our parents), go ahead and found your venture". The rector of the university she was attending at the time also backed her and said: "I will provide a place of your fancy on the university premises, free of charge. Utilities will also be paid by the university."

However, as her business took off and as she went through serious employee-related problems, she developed diabetes, upon which the pressure from her father reached its peak. This time, her father said: "I will not die in peace if I do not see you working as a civil servant before I die". She believed her father wanted to protect her from the harshness of the entrepreneurial world, so partly yielding, she found a job at a state university and outsourced her manufacturing operations to a local subcontractor. From then on she engaged only in R\&D work, both for her own venture and for the local subcontractor. However, unable to contemplate closing down her business, she re-registered her company with her mother as the legal owner. In this second instance of pressure from her father, she emphasized the critical role played by the emotional support from her husband and the knowledge support from her professor.

\section{Table 1. A structured summary of the case profile as far as the process of building relationships with} stakeholders is concerned: Case A

\begin{tabular}{|c|c|c|}
\hline Period & Challenger Stakeholder & Supporter Stakeholder \\
\hline I & $\begin{array}{l}\text { 5. Technical performance monitor, } \\
\text { appointed by the ministry to provide } \\
\text { technical control over the project, expects } \\
\text { full compliance with the predefined tasks } \\
\text { of the R\&D project proposal, which turn } \\
\text { out to be unattainable due to technical } \\
\text { reasons. } \\
\text { 7. Ministry suspends the project. }\end{array}$ & $\begin{array}{l}\text { 1. Professional former banker teaches the entrepreneur how to prepare a project proposal. } \\
\text { 2. Ministry provides seed funding. } \\
\text { 3. A friend from university becomes the entrepreneur's first employee. } \\
\text { 4. Parents let the entrepreneur use their summer house as a laboratory to develop the } \\
\text { prototype. } \\
\text { 6. The project performance monitor from the ministry defends the entrepreneur } \\
\text { concerning the negative report of the technical monitor. }\end{array}$ \\
\hline II & $\begin{array}{l}\text { 9. State funding arrives after a delay of } \\
\text { eight months. Entrepreneur has serious } \\
\text { cash management problems in this } \\
\text { interim period.. } \\
\text { 13. Personnel management issues arise. }\end{array}$ & $\begin{array}{l}\text { 8. New (current) partner joins the firm, bringing the necessary knowledge and extra } \\
\text { financing. } \\
\text { 10. An accountant provides key financial information and prevents bankruptcy. } \\
\text { 11. Family apartment is mortgaged to finance the venture until the promised state funds } \\
\text { arrive. } \\
\text { 12. Second group of progress monitoring staff for state funding provides practical } \\
\text { information on where to purchase materials at affordable prices. }\end{array}$ \\
\hline Major event & \multicolumn{2}{|c|}{ A new product is developed, a patent is granted, another patent application is pending. } \\
\hline
\end{tabular}


Table 2. A structured summary of the case profile as far as the process of building relationships with stakeholders is concerned: Case B

\begin{tabular}{|c|c|c|}
\hline Period & Challenger Stakeholder & Supporter Stakeholder \\
\hline I & $\begin{array}{l}\text { 4. Potential customer of the prototype is the } \\
\text { municipality, a monopsony arises, a situation in } \\
\text { which there is only one buyer, who, in the end, does } \\
\text { not buy the product. }\end{array}$ & $\begin{array}{l}\text { 1. Ministry provides seed funding. } \\
\text { 2. Performance monitoring staff of the ministry eases bureaucratic procedures. } \\
\text { 3. The partners divide the work of running their enterprise: E.C.. undertakes } \\
\text { paperwork, H.K. carries out engineering work. }\end{array}$ \\
\hline Major event & Partners change their business idea to one where their & customer is ready. \\
\hline II & $\begin{array}{l}\text { 5. Foreign customer orders a custom design product } \\
\text { as imagined by the end-user. }\end{array}$ & $\begin{array}{l}\text { 6. Foreign customer orders a product. } \\
\text { 7. Local suppliers act as sources of knowledge. } \\
\text { 8. International suppliers provide high-quality materials. } \\
\text { 9. Accountant helps decipher legal documents. }\end{array}$ \\
\hline Major event & A manager joins the team. & \\
\hline III & $\begin{array}{l}\text { 13. Foreign customer is the ONLY customer and the } \\
\text { start-up cannot afford to lose it, grows increasingly } \\
\text { dependent upon this customer. } \\
\text { 14. Employees do not comply with workplace safety } \\
\text { standards. }\end{array}$ & $\begin{array}{l}\text { 10. Foreign customer brings in increasing amounts of business from all over the } \\
\text { world. } \\
\text { 11. Employees work overtime. } \\
\text { 12. New manager reduces costs by cutting waste, improving inventory } \\
\text { management and employee morale. }\end{array}$ \\
\hline
\end{tabular}

Another example of balancing the influence of stakeholders is illustrated in Case A. Over the course of developing the prototype promised to the ministry, the start-up in Case A faced a very negative performance assessment report written by the academician who monitors their performance from a technical point of view. The author of the report expected full compliance with the pre-specified criteria outlined in the project proposal. However, as the research progressed, the entrepreneur found that those tests were not applicable to the materials they used in the project. The progress monitor was not satisfied with this explanation and filed a negative report with the ministry. Yet, a bureaucrat monitoring the project's progress at the ministry defended their progress at an assessment meeting and helped to mitigate the punishment imposed on the company, which was the 'suspension of payment for the project until a prototype was completed'. In this case, the startup survived pressure from the ministry due to help from a ministry official. In the second period, the same entrepreneur set up another start-up and endured a major financial crisis given that the expected state grant was delayed for eight months. Although this pressure from the state was not an intentional, the urgency of the matter exerted enough pressure on the entrepreneur that he was forced to resort to the support of two major stakeholders. Following the advice of a financial advisor and relying on cash generated by the mortgage on the founding partner's family apartment, the start-up survived this period. This story is a good case supporting the stakeholder theory [Mitchell et al., 1997], where power, legitimacy and urgency are all in play.

Each start-up developed relationships with different stakeholders according to the needs of the firm at a particular time. Of particular interest are the changes in a stakeholder's position, from challenger to supporter or vice versa, depending on what they expected of the firm. Case B is a good example of a start-up that adapted to the pressing circumstances at the initial stages of founding a business, who radically changed the business and stakeholders. At the time of the establishment of the firm in case B, the monopsony of the municipality exerted too many challenges to overcome. Once the start-up successfully developed the prototype they promised to the ministry, over that first year, the ministry's progress monitor helped the entrepreneurs in such a way that E.Ç., one of the founding entrepreneurs, expressed his gratitude and said: 'I would carry him on my back. However, in the

\section{Table 3. A structured summary of the case profile as far as the process of building relationships} with stakeholders is concerned: Case $\mathrm{C}$

\begin{tabular}{|c|c|c|}
\hline Period & Challenger Stakeholder & Supporter Stakeholder \\
\hline I & $\begin{array}{l}\text { 2. Father strongly opposes the entrepreneur's } \\
\text { idea of establishing a venture. }\end{array}$ & $\begin{array}{l}\text { 1. Ministry provides seed funding. } \\
\text { 3. Older brother, her boyfriend and a professor provide emotional support. } \\
\text { 4. Professor from her alma mater provides knowledge support. } \\
\text { 5. University's rector provides incubator conditions. }\end{array}$ \\
\hline Major event & Another state grant is received, which is used to & re some former classmates as employees. \\
\hline II & $\begin{array}{l}\text { 9. Some of the employees leave, one participates } \\
\text { in shady dealings with another company using } \\
\text { the assets of the entrepreneur. } \\
\text { 10. Customers' receivable collection takes time } \\
\text { and is sometimes impossible. } \\
\text { 12. Father pressures the entrepreneur to shut } \\
\text { down her business entirely. }\end{array}$ & $\begin{array}{l}\text { 6. New employees contribute to growing manufacturing operations. } \\
\text { 7. University still provides incubation (free space and utilities). } \\
\text { 8. Professor and boyfriend still provide emotional support. } \\
\text { 11. New customers are found through connections made during a workshop for } \\
\text { female entrepreneurs. }\end{array}$ \\
\hline Major event & The entrepreneur develops diabetes, finds a job a & a civil servant, but continues work with her start-up. \\
\hline III & 13. Father still objects to the start-up. & $\begin{array}{l}\text { 14. Mother becomes a legal partner; the entrepreneur's commercial success changes } \\
\text { her father's attitude towards the venture, though he never admits it. } \\
\text { 15. Husband takes over night-time installations. } \\
\text { 16. The professor and the husband continue to provide psychological support. } \\
\text { 17. Professor continues to act as a source of knowledge and know-how. } \\
\text { 18. Local subcontractor takes over manufacturing. } \\
\text { 19. Customers' references bring in new orders and clients. }\end{array}$ \\
\hline
\end{tabular}


end, the municipality that was the founders' only client, chose not to buy their product. This situation forced the partners to act and accept an order from a foreign firm they had previously known. This firm's sustained demand gave life blood to the start-up. However, as time progressed, the company became dependent on this single client, which posed enormous challenges. E.Ç. said: "Our customer is a 200 -year-old firm in Austria... to this day, we have never marketed anything. The firm in Austria is a team for us... We cannot do this business without this Austrian firm". Thus, this stakeholder who initially helped breathe life into the venture became a trap. As Schlange [Schlange, 2009] indicates, this is a case of a stakeholder relationship changing as the venture grows. The power of this single stakeholder stems from the fact that if this customer stopped its orders, then the firm would have no other customer to turn to. Thus, it has considerable influence over the start-up and this stakeholder's power is counterbalanced and somewhat offset by the support from the firm's three other stakeholders: local suppliers, employees, and international suppliers. Local suppliers provide knowledge and the international suppliers provide high-quality materials and components for the custom-made products. Finally, the employees play a key role by working overtime to meet shipment deadlines. The evolution of this start-up also makes a case for the dynamic capabilities theory, which states that in order to meet the demands of dynamic marketplaces, firms need to develop capabilities to acquire resources and learn new ways to deploy those resources to meet the demands of the market [Zahra et al., 2006]. Dynamic capabilities are defined as "the capacity of an organization to purposely create, extend and modify its resource base" [Helfat et al., 2007, p. 4]. The change of the business in case B from one with no market to one with a client willing to place orders (indicating a potential market) is certainly an example of the deliberate reorientation of a firm towards the actual needs of the market.

In case A, after going through a number of periods of financial turmoil, eventually resorting to a business angel's investment in return for $30 \%$ of the firm, this entrepreneur's actions are also an example of 'deliberate resource base extension. Thus, these cases indicate that these entrepreneurs, were able to read the market and determine the needs of the start-ups before finding the relevant resources and new stakeholders, who could provide them.

\section{Learning emerges as a by-product of stakeholder relationships}

The entrepreneurs' approach to learning could be summarized in this one instance. One day, the founding entrepreneur's partner in case A showed him an old photo and said: 'Look, we are still not rich'. He objected by saying: 'On the contrary, we are awfully rich, we have learned so much. We did not know any of what we now know'. The interactions with stakeholders create opportunities for learning. For the entrepreneurs in case B, designing somebody's dream chandelier requires both creativity and technical problem solving, which is unique to every customer order. Therefore, in order to solve a different problem each time, they first start out with their own solution, then turn to local suppliers to refine the technical details of the complete manufacturing processes. E.C.. said: "When we founded the firm, we were located in a technopark, but in time, we opened up a place in OSTIM. Being located in OSTIM is the best thing when you need help with anything, for instance, welding. At the university, I had learned about welding in one chapter but here, there are people who have been welding for 30 years. We go and ask for their opinion and they say, "if I did not like you, I would not help" but then they do.... In return, we help that person choose the type of computer he needs to buy for his son... For us this is a trivial thing". For the entrepreneur in Case C, her knowledge source was her professor. She said: "My professor was always there for me even when he was exhausted from work. When I ask for help, he drops everything else. This person is also a dean, so he has administrative work in addition to academic work, but still he helps me. He does not even expect anything in return." As we can see from these two cases, the interaction between the stakeholders and the entrepreneurs gives the latter access to detailed knowledge on rather specific topics.

While having supportive stakeholders who are willing to share their knowledge with the entrepreneurs is a critical element, these entrepreneurs need to learn quite a lot on their own as well. For instance, the entrepreneur in case C said: "Whenever I asked for help from my accountant, he would say you can find this out on your own, so I had to learn. Sure, he gave some guidance, but I learned tax and social security procedures, all of those, on my own. Now I know enough not to depend on anyone else concerning accounting or legal matters." E.Ç., one of the founding partners in Case B, also said: "We learned tax matters and other legal matters by making mistakes. They were not lethal mistakes, thank God... Today we read all the laws and regulations related to us.... When we read a paragraph for the eighth time and still do not comprehend it, we will then resort to the financial advisor. He does not answer us a couple of times, then, we take the material to him at night and tell him that if he does not read the material, we will find another financial advisor. Then he reads and advises". These issues of 'learning by doing' have to do with investing time, but there are other instances where investing time is certainly not enough, these are examples of when 'people matter'. In both Case A and Case C, where university graduates were hired as employees, they were treated as equals by the founding entrepreneurs, however, both entrepreneurs remarked that such treatment was inappropriate and they learned this lesson the hard way. The founding partner in case A said: "There is nothing technical that cannot be solved, but human relations are tough. For instance, we used to distribute bonuses following the closure of a project. We should not have done this. Some people worked only for the bonus.... What's more, they regret their work with you in absence of a bonus and say this to your face." The entrepreneur in Case C, after the backhanded dealings of her employee, could not take the matter to court as she had no contract with the employee, who happened to be her 'friend'. After the fact, she said: "Coworkers should be people you can command and they should sign a confidentiality agreement and a non-competition agreement when joining the firm". These instances demonstrate that the entrepreneurs benefited from 'learning by doing' [Cope, 2005], which consists of lessons learned from one's own mistakes, or lessons learned after encountering and solving problems [Deakins, Freel, 1998; Young, Sexton, 1997]. Dalley and Hamilton (2000) underline the importance of experience: "It seems accepted that there are no shortcuts in the learning process, that surviving various 'trials by fire' is almost a rite of passage, and that there can never be any substitute for experience" [Dalley, Hamilton, 2000, p. 55]. 
Learning is such a key part of their venture that these entrepreneurs seek willingness to learn in their stakeholders, for instance, their employees. The founding partner in Case A said: “...when we are recruiting, we try to see if this person is curious, if they want to learn. For instance, recently we recruited a university graduate, whom we found through his website where he exhibited a quadcopter he made completely on his own. We were so excited to find such a person. He was eager to work with us. Then my partner assigned him a project to assess his abilities. This person could not do the project and was discouraged right away. Even though we tried to talk to him and make him stay with us, he went back to Adiyaman (his hometown). This taught us we should not push people too far ... What we care about is the employee's interest in problem solving... We pose a problem to him. If he is interested on his own, that is what we are after." A similar approach towards employees is also present in case B where E.Ç said: "We encourage our employees to further their education, by either helping them with their homework assignments or tutoring them on some of their class material." These instances indicate that they seek 'curiosity' and 'willingness to work hard to learn' in their employees. Yet as these entrepreneurs are not experienced in 'people management', they learn from their own mistakes, they learn how to better manage the employees. As E.Ç. in case B said: "Sometimes you may need to argue with your own staff to make them wear safety glasses. We do not want anything bad to happen to the people we work with. Money is earned and lost, but you have to keep the team going."

Learning also takes place as incidents unfold with customers and suppliers. The entrepreneur in Case C said: "There are so many people from whom I still cannot collect my receivables. ... For instance, one day before my wedding, I delivered a product to a customer and did not ask for payment then. Later, when I asked for the payment, the customer said, 'You should not have delivered the product without receiving the payment,' and this was supposed to be a lesson to me. He has not paid to this day... Today, I still deliver my products and still do not insist on immediate payment, but at least I make them sign a paper saying they received the items". The founding partner in Case A said: "Previously, we were rather naive, but now all these delays in cash collections either from customers or from the state taught us to be extra cautious... Although we signed an agreement with a business angel, I am preparing my budget as if that financing will never arrive..." The firm in case B suffered from suppliers overcharging it for materials. E.Ç. from case B said: "Let's say I bought a component from you and then I check the price on the market and realize that the market price is a third of what I paid. This happens all the time. Even the people you trust can do this once you stop price scanning."

In the literature, these experiences are referred to as the "affective" mode of learning, which is a personally experienced type of learning. The "affective mode of learning finds expression through 'being there, through immersion in an experience" [Postle, 1993, p. 33]. The different learning schemes of the entrepreneurs are summed up in the words of Gibb (1997) as: "The predominant contextual learning mode in this environment is that of...learning from peers; learning by doing; learning from feedback from customers and suppliers; learning by copying; learning by experiment; learning by problem solving and opportunity taking; and learning from making mistakes" [Gibb, 1997, p. 19].

\section{One's reputation is earned through ethical and passionate business practices}

Some of the entrepreneurs' business practices helped them gain a good reputation in the eyes of their stakeholders, particularly customers. The entrepreneur in case $\mathrm{C}$ emphasized the contribution of ethical business practices to her firm's reputation: ".. a customer comes asking for the development of a product. If we find the product on the market, we refer the customer to that firm. Most people do not behave in this way. They purchase the item and resell it to the customer. However, our behavior leaves an impression of a 'trustworthy' firm and this always has a positive return". The entrepreneurs in case B recall the first time they shipped their first order of 32 chandeliers abroad. While expecting the 'appreciation of their work' from the end-user, they received the news that all of the chandeliers were damaged during the shipment. Therefore, they had all of the products shipped back, fixed them one by one, and this time carefully packaged them for a safe trip. Eventually, the enduser was happy with the result and their behavior proved their 'trustworthiness' in the eyes of their customer. The literature underlines the significance of ethical business practices: "Personal reputation is an important asset, because it reduces uncertainty concerning future behavior by signaling that the individual is trustworthy and has the necessary abilities to deal with workplace demands" [Neves, Story, 2015, p. 172].

In his eight years of research on entrepreneurs Sirolli [Sirolli, 2003] concluded that the essential ingredient of entrepreneurship is 'passion'. E.Ç. in Case B said: "Have you ever seen a cat that could ignore playing with a ball of yarn? To us that is how a new order is, we like solving problems... I can do any other job, like sweeping floors or working in sewage or xeroxing at a bank, but people would think I am a psychopath because when I am xeroxing a document, that paper has to be placed perfectly in the machine.... We have a lot of obsessions like this. If something does not turn out as it is supposed to, we continue to work on it until we are satisfied... We are constantly in search of excellence..." The same passion for new product development is also apparent in the entrepreneur in case $\mathrm{C}$ who said: "I do not sell an existing product just because there is a market for it. It is something that I can sell, but I do not get any joy out of it. I like developing new products." The entrepreneur in case A said: "My partner and I have a notebook in which we write down our business ideas. We like developing new things. Our goal in the future is to buy 10-20 acres of land and start an R\&D center where people can live and work." The passion to generate new products, meet technological challenges head-on is a common driving force found among these three entrepreneurs.

\section{Discussion}

Most research assumes that family will be supportive of a new venture [Brüderl, Preisendörfer, 1998]. Family is seen as provider of emotional support in the establishment stage of a venture and a source of tacit knowledge. The entrepreneur enjoys trusted feedback from their family members regarding business ideas [Rosenblatt et 
al., 1985]. As entrepreneurs prefer to discuss their ideas in confidence, they feel secure talking to their family members [Greve, Salaf, 2003]. Furthermore, family also often acts as the provider of initial capital [Anderson et al., 2005; Greve, Salaf, 2003; Conti et al., 2013]. However, the findings of our work revealed some unexpected conclusions. One was the case of family acting as the key provider of critical finance by mortgaging the family apartment. This case is in line with the literature [Bygrave et al., 2003], but then there was the case a family member acting as the biggest obstacle to the entrepreneur's start-up. One piece of research [Anderson et al., 2005] described the case of an entrepreneur who would not let his son work at his firm thinking that it would damage his son's development. Thus, the following could be proposed:

Hypothesis 1: Family members' strong opposition to an entrepreneur's start-up efforts could simply arise in order to 'protect' the entrepreneur from potential harm caused by such a risky endeavor.

Yet such a proposition merits further research because this specific case could be an idiosyncratic one. First, whether or not this is a unique case should be studied and secondly, if this case is not an anomoly, then more data should be collected to elucidate the reasons behind such 'protective' behavior.

In Turkey, while the state aims to support entrepreneurship, the people who carry out these well-intended policies may not be acting in compliance with the state's final goal. As the above cases illustrate, the performance monitoring staff of the state, who are appointed to assess the performance of start-ups, may either pave the way for the entrepreneur, clearing the road of bureaucratic obstacles, or may kill a start-up in its infancy for not complying with the myriad bureaucratic procedures. Since these people are 'acting' stakeholders in the name of the state, the entrepreneur needs to adhere to the predefined success criteria of the project expected by the state. In the literature, researchers suggest that this inflexible attitude of the state staff might be explained by 'causation driven logic' while the problem-solving and creativity-based approach of the entrepreneurs could be classified as effectuation (situational) driven logic [Sarasvathy, 2008].

Sarasvathy explains the difference between causal and effectual (situational) thinking by giving the example of two chefs [Ibid.]. In the causal case, the chef starts the cooking process by first picking a menu. Then he finds the recipes for each item on the menu. Next, he does the necessary shopping for ingredients, arranges the pots and pans, and all the relevant other material and finally cooks the meal. The causal process starts with the goal and proceeds with consecutive, well-planned steps to achieve the goal. In the effectual case, the chef first checks the kitchen to see what ingredients and materials are available. Then he designs the menus based on what he has on hand. As a matter of fact, the menu is created along with the meal. The effectual chef starts with what he finds in the kitchen, and 'designs' possible dishes according to the ingredients on hand.

Dutta and Thornhill [Dutta, Thornhill, 2014, p. 156] state that entrepreneurs "may become compelled to adopt a causation-oriented cognitive logic for the venture under pressure from external investors that expect the entrepreneur to provide a detailed, incremental business plan with clearly articulated future scenarios for the venture ..." In the three cases that were presented in this paper, the pressure from the state was exerted if the firms did not follow causal logic and state officials empathized compliance with the prespecified plans that were made before the venture was even started. Furthermore, a study based on six years of longitudinal data [Honig, Samuelson, 2009] finds no significant positive relationship between business planning and commercial performance. Thus, the following proposition could be made based on the cases analyzed here.

Hypothesis 2: Differences between the mindsets of the state and the entrepreneur, such as those between causal and situational logic, prematurely end potentially successful ventures.

Ethical and passionate business practices are common traits that these three entrepreneurs share. The ethical conduct of a business reflects their stance in the business world and they believe this has benefits in the form of 'a good reputation', which may bring in future stakeholders, i.e., customers. At this point, one wonders, what do the customers feel about the ethical practices of a no-name start-up? How would the passionate attitude of these entrepreneurs affect their stakeholders? These two questions lead one to propose the following:

Hypothesis 3: Ethical and passionate business practices leave a positive impression on third parties cooperating with the start-up, and they may in turn become stakeholders in the future due to the traits they witness before investing in the enterprise.

\section{Conclusion}

The aim of this paper was to explore the process of building relationships with stakeholders carried out by R\&Dbased start-ups established after receiving the techno-entrepreneurship grant in Turkey. To this end, in-depth interviews with the founders of three start-ups were conducted and analyzed. When analyzed chronologically, the stakeholder formation process exhibited a structure where challenger and supporter stakeholders were present at two opposing sides of the start-up where the entrepreneur benefited from the counterbalancing effect of these forces. Two major stakeholder groups emerged at the founding stage of the businesses: the family members and the state's grant-handling officers.

The predominant finding in the literature was the supportive role of the family, however, in one of the cases, we found a profound opposing force posed by one of the family members. Is this opposing force of the family a unique case or is it representative of a subset of techno-entrepreneurs in Turkey? This should be the subject of further study. Secondly, the logic of the state's techno-entrepreneurship fund monitoring staff seems to be a vital factor in the sustainability of the start-ups and the relationships in which entrepreneurs choose to invest. Thus, such staff's flexibility in understanding the mindsets of the entrepreneurs should be studied further. Finally, the ethical and passionate conduct of business by these start-ups could be a factor drawing third parties in to become stakeholders of these new firms. Therefore, this too could be the subject of further research. 


\section{References}

Anderson A.R., Jack S.L., Dodd S.D. (2005) The role of family members in entrepreneurial networks: Beyond the boundaries of the family firm. Family Business Review, vol. 18, no 2, pp. 135-154.

Bazerman M.H., Neale M.A. (1992) Negotiating rationally, New York: Free Press.

Brüderl J., Preisendörfer P. (1998) Network support and the success of newly founded businesses. Small Business Economics, vol. 10, no 3, pp. 213-225.

Bygrave W.D., Hay M., Ng E., Reynolds P. (2003) A Study of Informal Investing in 29 Nations Composing The Global Enterprise Monitor. Venture Capital: An International Journal of Entrepreneurial Finance, vol. 5, pp. 101-116.

Conti A., Thursby M., Rothaerme F. (2013) Show Me the Right Stuff: Signals for High-Tech Startups. Journal of Economics \& Management Strategy, vol. 22, no 2, pp. 341-364.

Cope J. (2005) Toward a dynamic learning perspective of entrepreneurship. Entrepreneurship Theory and Practice, vol.29, no 4, pp. 373-397.

Coviello N.E., Jones M.V. (2004) Methodological Issues in International Entrepreneurship Research. Journal of Business Venturing, vol. 19, no 4, pp. 485-508.

Dalley H., Hamilton B. (2000) Knowledge, context and learning in the small business. International Small Business Journal, vol. 18, no 3, pp. 51-59.

Daniels C., HoferC. (1993) Characteristics of successful and unsuccessful entrepreneurial faculty and their innovative research teams. Frontiers of Entrepreneurship Research (eds. N. Churchill, S. Birley, W. Bygrave, J. Doutriaux, E. Gatewood, F. Hoy, W. Wetzel), Wellesley, MA: Babson College, pp. 598-609.

Deakins D., Freel M. (1998) Entrepreneurial learning and the growth process in SMEs. The Learning Organisation, vol. 5, no 3, pp. 144-155.

Dutta D.K., Thornhill S. (2014) Venture Cognitive Logics, Entrepreneurial Cognitive Style and Growth Intentions: A Conceptual Model and an Exploratory Field Study. Entrepreneurship Research Journal, vol. 4, no 2, pp. 147-166. DOI: $10.1515 /$ erj-2012-0004.

Eriksson P., Kovalainen A. (2008) Qualitative methods in business research, London: Sage.

Evers N., Andersson S., Hannibal M. (2012) Stakeholders and Marketing Gapabilities in International New Ventures: Evidence from Ireland, Sweden, and Denmark. Journal of International Marketing, vol. 20, no 4, pp. 46-71.

Freeman R.E. (1984) Strategic management: A stakeholder approach, Cambridge, MA: Pitman.

Frooman J. (1999) Stakeholder influence strategies. Academy of Management Review, vol. 24, pp. 191-205.

Gans J.S., Stern S. (2003) The product market and the market for ideas: Commercialization strategies for technology entrepreneurs. Research Policy, vol. 32, no 2, pp. 333-350.

Gibb A.A. (1997) Small firms' training and competitiveness: Building on the small business as a learning organization. International Small Business Journal, vol. 15, no 3, pp. 13-29.

Greve A., Salaff J.W. (2003) Social networks and entrepreneurship. Entrepreneurship Theory and Practice, vol. 28, no 4, pp. 1-22.

Helfat C.E., Finkelstein S., Mitchell W., Margaret P., Singh H., Teece D., Winter S.G. (2007) Dynamic Capabilities: Understanding Strategic Change in Organizations, London: Blackwell.

Honig B., Samuelson M. (2009) Business planning and venture level performance: Challenging the institution of planning (Swedish Entrepreneurship Forum WP no 05), Örebro: Örebro University Available at: http://entreprenorskapsforum. se/wp-content/uploads/2013/03/WP_05.pdf, accessed 31.01.2016.

Julien P. (1995) New technologies and technological information in small businesses. Journal of Business Venturing, vol. 10, no 6, pp. 459-475.

Lawler E.)., Yoon J. (1996) Commitment in exchange relations: Test of a theory of relational cohesion. American Sociological Review, vol. 61, no 1, pp. 89-108.

Maxwell J.A. (1996) Qualitative Research Design: An Interactive Approach, Thousand Oaks, CA: Sage.

Mitchell R.K., Agle B.R., Wood D.J. (1997) Toward a theory of stakeholder identification and salience: Defining the principle of who and what really counts. Academy of Management Review, vol. 22, no 4, pp. 853-886.

MSIT (2014) 2009-2014 Teknogirişim Dönem Raporu [2009-2014 Techno Entrepreneurship Report], Ankara: Turkish Ministry of Science, Industry and Technology. Available at: http://sagm.sanayi.gov.tr/userfiles/file/ Teknogiri\%C5\%9Fim\%20Sermayesi\%20Deste\%C4\%9Fi/TGSD\%2009-14\%20D\%C3\%96NEM\%20RAPORU\%20 REV\%C4\%B0ZYON\%200409.pdf, accessed 19.03.2016 (in Turkish).

Neves P., Story J. (2015) Ethical Leadership and Reputation: Combined Indirect Effects on Organizational Deviance. Journal of Business Ethics, vol. 127, pp. 165-176.

OECD (2003) The Policy Agenda for Growth, Paris: OECD.

Patton M.Q. (2002) Qualitative Research and Evaluation Methods, Thousand Oaks, CA: Sage.

Pfeffer J., Salancik G. (1978) The external control of organizations: A resource dependence perspective, New York: Harper \& Row.

Postle D. (1993) Putting the Heart Back into Learning. Using Experience for Learning (eds. D. Boud, R. Cohen, D. Walker), Buckingham: SRHE, Open University Press, pp. 33-45.

Rosenblatt P.C, de Mik L., Anderson R.M., Johnson P.A. (1985) The Family in Business, San Francisco, CA: Jossey-Bass.

Sarasvathy S., Venkatamaran S. (2011) Entrepreneurship as Method: Open Questions for an Entrepreneurial Future. Entrepreneurship Theory and Practice, vol. 35, no 1, pp. 113-135. DOI: 10.1111/j.1540-6520.2010.00425.x

Sarasvathy S.D. (2001) Causation and effectuation: Toward a theoretical shift from economics inevitability to entrepreneurial contingency. Academy of Management Review, vol. 26, no 2, pp. 243-263.

Sarasvathy S.D. (2008) Effectuation: Elements of Entrepreneurial Expertise, Cheltenham: Edward Elgar.

Schlange L.E. (2009) Stakeholder identification in sustainability entrepreneurship: The role of managerial and organisational cognition. Greener Management International, vol. 55, pp. 13-32.

Scottish Executive (2001) A Smart Successful Scotland: Ambitions for the Enterprise Networks, Edinburgh: HM Stationary Office.

Sirolli E. (2003) Ripples from the Zambesi. Passion. Entrepreneurship and the rebirth of local economies, Gabriola Island, Canada: New Society Publishers.

Steyaert C. (1997) A qualitative methodology for process studies of entrepreneurship: Creating local knowledge through stories. International Studies of Management and Organization, vol. 27, no 2, pp. 13-33.

Strauss A.L., Curbin J.M. (1990) Basics of Qualitative Research: Techniques and Procedures for Developing Grounded Theory, Thousand Oaks, CA: Sage.

Thompson L., Gentner D., Loewenstein J. (2000) Avoiding missed opportunities in managerial life: Analogical training more powerful than individual case training. Organizational Behavior and Human Decision Processes, vol. 82, no 1, pp. 60-75.

Young J.E., Sexton D.L. (1997) Entrepreneurial Learning: A Conceptual Framework. Journal of Enterprising Culture, vol. 5, no 3, pp. 223-248.

Zahra H., Sapienza J., Davidsson P. (2006) Entrepreneurship and Dynamic Capabilities: A Review, Model and Research Agenda. Journal of Management Studies, vol. 43, no 4, pp. 917-955. 